\title{
THE EUROPEAN UNION FUNDS IN THE IMPLEMEN- TATION OF THE CONCEPT OF SUSTAINABLE DEVELOPMENT IN THE CONTEXT OF FINANCING PROJECTS RELATED TO THE RE- USE OF EUROPE'S CULTURAL HERITAGE
}

\section{ZDZISŁAWA ELŻBIETA NIEMCZEWSKA}

Poznań University of Economics and Business, Faculty of International Business and Economics, POLAND e-mail: zdzislawaniemczewska@gmail.com

RECEIVED
ACCEPTED
JEL
CLASSIFICATION

KEYWORDS

ABSTRACT
18 January 2018

2 September 2018

F63, 019, O44, Q01, Q56, R11, R31, R51, R58

sustainable development, cultural heritage, European funds, European Union, adaptive re-use of cultural heritage

The subject of this article is to bring closer to readers, especially the local and regional authorities (as beneficiaries of EU funds) knowledge about opportunities offered by the cultural heritage in the implementation of the sustainable development principles in all dimensions: economic, social, environmental and cultural. Local authorities are often unable to cope with the proper use of available resources of cultural heritage, and although the functioning and development of cities and regions is largely based on the principle of sustainable development (at least according to development strategies), it is often difficult for local authorities to see the opportunity in available heritage to create benefits for society, economy, environment and culture in a given area. And although the local governments are aware of the potential for funding from the European Union in various areas, they often overlook the possibility of obtaining funding specifically related to the cultural heritage. This is a barrier in the implementation of UE policies related to cultural heritage in Europe especially in countries of Central and Eastern Europe. The article also acquaints the readers with the European Union policy on the cultural heritage of Europe and the financing of projects related to its use in programming period 2014-2020.

\section{Introduction}

European cultural heritage is a very important element in the lives of Europeans. The European Union countries abound in various sorts of monuments, places of worship or unique features of nature which (because of their various values) nations decide to protect. This protection most often takes the form of legal protection and conservation and for many regional and local authorities it is a problem, as, in their concept, these are cost driving 
factors (e.g. in the case of monuments that must be maintained and must not be destroyed but they do not fulfil any role in creating of added value apart from their historical value) or a factor significantly limiting the expansion of cities (e.g. when in their area is a zone protected by law). Local authorities are often unable to cope with the proper use of available resources of cultural heritage, and although the functioning and development of cities and regions is largely based on the principle of sustainable development (at least according to development strategies), it is often difficult for local authorities to see the opportunity in available heritage to create benefits for society, economy, environment, and culture in a given area. And although the local governments are aware of the potential for funding from the European Union in various areas, they often overlook the possibility of obtaining funding specifically related to cultural heritage. This is a barrier to the implementation of UE politics related to cultural heritage in Europe especially in countries in central and eastern Europe.

The purpose of this paper is to make aware the interested stakeholders (including local governments, as beneficiaries of EU funds), the importance and potential of having a variety of assets in the form of a broadly understood cultural heritage and make them aware that Europe's cultural heritage is a very important stimulating factor for smart, sustainable growth not only at the level of cities or regions but also at the level of the Member States and the whole European Union.

\section{What do we mean by Cullupal Heritage?}

In the literature of the subject or in various types of studies, we encounter a different interpretation of the broadly understood cultural heritage. For many years this concept has evolved. For the purposes of this study, the most accurate, most concise, and most accurately to the subject of our deliberations, the definition can be found in Wikipedia, which cultural heritage defines as follows:

Cultural heritage is the legacy of physical artefacts and intangible attributes of a group or society that is inherited from past generations. Cultural heritage includes tangible culture (such as buildings, monuments, landscapes, books, works of art, and artefacts), intangible culture (such as folklore, traditions, language, and knowledge), and natural heritage (including culturally significant landscapes, and biodiversity) (Wikipedia, 2017).

An interesting interpretation of cultural heritage cites a report entitled: "Dziedzictwo kulturowe ma znaczenie dla Europy. Skrót raportu": Cultural heritage is part of the past that we choose in the present for our contemporary economic, cultural, political and social goals and which we choose to pass on to future generations. Heritage includes works of man and nature with special cultural or scientific value for the development of civilization. It is always subject to contemporary interpretation, which gives it a new meaning. Traditionally, they are divided into cultural and natural, and the cultural heritage in turn - material (movable and immovable) and intangible (Międzynarodowe Centrum Kultury, 2015, p. 11).

Cultural property includes the physical, or tangible cultural heritage, such as artworks. These are generally split into two groups of movable and immovable heritage. Immovable heritage includes buildings (which themselves may include installed art such as organs, stained glass windows, and frescos), large industrial installations or other historic places and monuments. Moveable heritage includes books, documents, moveable artworks, machines, clothing, and other artefacts, that are considered worthy of preservation for the future. These include objects significant to the archaeology, architecture, science or technology of a specified culture.

Intangible cultural heritage consists of non-physical aspects of a particular culture, more often maintained by social customs during a specific period in history. The concept includes the ways and means of behaviour in 
a society and the often formal rules for operating in a particular cultural climate. These include social values and traditions, customs and practices, aesthetic and spiritual beliefs, artistic expression, language and other aspects of human activity (Wikipedia, 2017).

As a natural heritage, according to Article 2 of the UNESCO World Heritage Convention we consider: Natural features consisting of physical and biological formations or groups of such which are of outstanding universal value from the aesthetic or scientific point of view; geological and physiographical formations and precisely delineated areas which constitute the habitat of threatened species of animals and plants of outstanding universal value from the point of view of science or conservation; natural sites or precisely delineated natural areas of outstanding universal value from the point of view of science, conservation or natural beauty (UNESCO, 1972, p. 2).

The above definitions indicate that cultural heritage is an important part of the surrounding us reality and we encounter it very often in our daily lives.

\section{Areas of cultural heritage influence in the context of sustainable development principles}

Cultural heritage, undoubtedly, is an important element of the attractiveness of regions and cities, especially those with recognized and well-known heritage. For cities and regions with less recognized heritage, using it and achieving positive results in line with the sustainability goals may pose some difficulties, especially in the initial phase of adaptive re-use planning and applying for EU funding. Most often, regional and local authorities, when planning all activities, including those related to the use of cultural heritage, focus their attention mainly on achieving economic results. On the one hand, it is understandable but it is important to remember that the remaining elements of the idea of sustainable development (social, environmental, cultural) are equally important and indirectly contribute to many benefits, including the economic area (e.g. visual attractiveness of place which creates culture attracts also potential tourists, investors or the artistic community, which undoubtedly has an impact on the economy of this place). Heritage cannot be valued only economically, heritage is also about development (Mkadem, Zakriti, Nieuwenhuysen, 2018, p. 4). There is the need for consideration of the benefits of preservation and contemporary use of cultural heritage from different points of view, i.e. not only aesthetic and historical heritage, but also from the perspective of development and implementation of public policies and strategies, including efficient use of public funds and in the context of overall socio-economic development (Murzyn-Kupisz, 2010, p. 19).

Elements of sustainable development in case of cultural heritage interpenetrate and influence each other.

Just as the importance and the way of obtaining economic benefits through the use of cultural heritage is clear and understandable for local authorities the remaining areas of influence (their importance and their effects) may be considered as less important or difficult to obtain. It should be borne in mind, however, that the procedure for applying for EU funds for the adaptive re-use of cultural heritage most often needs to show in the applications that the project will contribute to the realization of sustainable development in all its areas. It derives, for example, from the "EUROPE 2020. A strategy for smart, sustainable and inclusive growth" issued by the European Commission which one of the priorities is sustainable development - supporting a resource-efficient economy (European Commission, 2010 , p. 10) or from one of the tools for the implementation of this strategy - the Horizon 2020 Framework Program, with a budget of $€ 80$ billion for 2014-2020.

It is therefore worth mentioning here a noteworthy positive example of the impact of heritage on the environmental area, as presented in the report „Cultural Heritage counts for Europe. Full report”: Reusing and repairing existing building stock has clear environmental benefits, with increasing evidence that the level of energy 
efficiency of pre-1890 public buildings at least matches, and sometimes exceeds, that of the most sophisticated modern buildings. From an environmental standpoint, the embodied energy of existing buildings is one of the most compelling arguments for preserving them. Embodied energy is a quantitative measure of the energy consumed during the extraction, manufacture, and transportation of materials as well as the construction phase. When a building is demolished, the environmental cost includes the lost embodied energy and increase in landfill waste. (...) In addition, the outcome of the last meeting of the ECTP in June 2014 in Brussels defines the environmental impact of built heritage on Europe's sustainability as follows: minimising unnecessary demolition of buildings, reducing transport impact, connecting with the natural environment. (...) Maintaining existing structures contributes to reducing urban sprawl, prolonging the physical service life of buildings and building parts, supports wasteavoidance and preserves embodied energy (CHCfE Consortium, 2015, p. 80).

The significance and influence of cultural heritage in of particular areas related to sustainable development are presented in Figure 1.

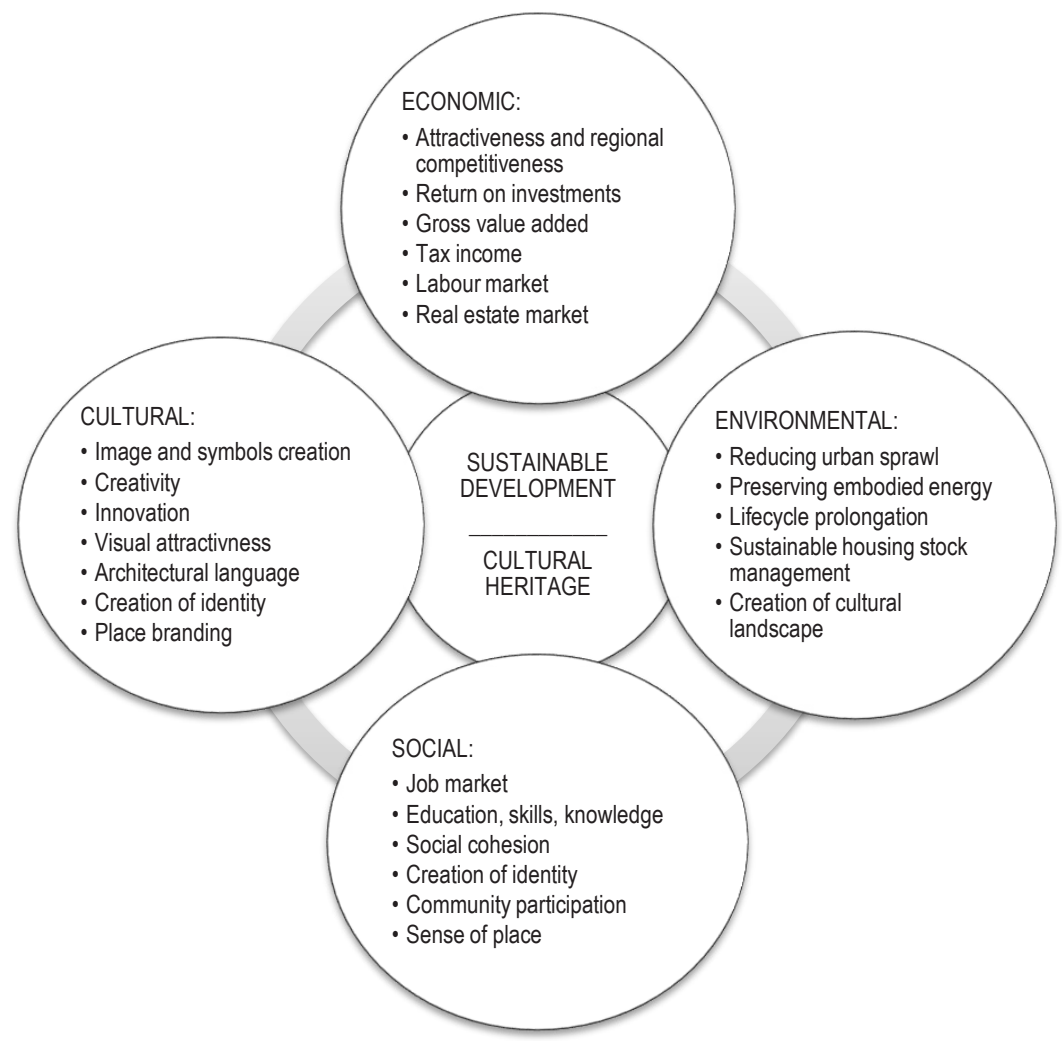

Figure 1. Areas of cultural heritage in the context of sustainable development idea

Source: own, based on the report: Cultural heritage counts for Europe. Full report, CHCfE Consortium, 2015. 
The indisputable fact is, that around common cultural heritage in Europe the entire tourism industry is growing, changing the development and employment structure of many cities and regions in Europe (Jurkiewicz-Eckert, 2003, p. 94). Rich cultural heritage is one of the important resources of Europe, so it is worth to use its potential.

\section{The European Union policy on the cultural heritage of Europe and the financing of projects related to its adaptive re-use}

As mentioned above, the European Union supports activities related to the adaptive re-use of the cultural heritage of the European Union countries. This has been identified in many documents issued by EU institutions. One of the essential documents in which the importance of European cultural heritage is mentioned is the Preamble of the Treaty on the European Union whose signatories are "inspired by the cultural, religious and humanist heritage of Europe". Article 3, paragraph 3 of the Treaty on the European Union stipulates that the European Union "... respect its rich cultural and linguistic diversity, and shall ensure that Europe's cultural heritage is safeguarded and enhanced" (Official Journal of the European Union, 2016, pp. 15, 17). The importance of Europe's cultural heritage has also been defined in Article 167 of the Treaty on the Functioning of the European Union. This article provides the following: "The Union shall contribute to the flowering of the cultures of the Member States while respecting their national and regional diversity and at the same time bringing the common cultural heritage to the fore" (Official Journal of the European Union, 2016, p. 121).

Cultural heritage is a priority in the actions of the Council of the European Union. In the Resolution of the Council of 16 November 2007 on "The European Agenda for Culture" the Council stressed, that "... culture and creativity are important drivers for personal development, social cohesion, economic growth, creation of jobs, innovation and competitiveness" (Official Journal of the European Union, 2007, p. 1).

One of the specific objectives of "The European agenda for culture in a globalizing world" issued by The European Commission is: Develop creative partnerships between the cultural sector and other sectors (ICTs, research, tourism, social partners, etc) to reinforce the social and economic impact of investments in culture and creativity, in particular with regard to the promotion of growth and jobs and the development and attractiveness of regions and cities (European Commission, 2007, p. 10).

In its other Communication "Towards an integrated approach to cultural heritage for Europe" cultural heritage is recognized as a catalyst for creativity and growth. It points to opportunities and the need to exploit the potential of cultural heritage to stimulate local and regional development. The Communication stated that: Conserving, promoting and managing cultural heritage is currently well supported under the EU Structural and Investment Funds (ESIF). In 2007-2013, the European Regional Development Fund allocated $€ 3.2$ billion for protecting and preserving cultural heritage, $€ 2.2$ billion to develop cultural infrastructure and $€ 553$ million for cultural services, which also benefited cultural heritage. In 2014-2020, ESIF investments in heritage will remain eligible, under certain conditions, through direct funding, but also through investment in urban regeneration, sustainable development and support to small to medium-sized enterprises (SMEs) (European Commission, 2014, p. 10).

The European Regional Development Fund offers funds to cover a wide spectrum of activities in the public and private sectors (in particular SMEs) and non-profit pursuing investments that contribute directly to the fund's objectives and investment priorities. Investments in small-scale cultural infrastructure as part of a territorial strategy should contribute both to the development of endogenous potential and to the promotion of social inclusion and 
quality of life, particularly among marginalized communities, by improving their access to cultural and recreational services in both urban and rural contexts.

European Agricultural Fund for Rural Development offers support for the preservation and enhancement of the rural heritage (in 2007-2013 allocated to them $€ 1.2$ billion).

European Maritime and Fisheries Fund offers funding for projects implemented by local communities on cultural heritage in fishing areas as well as maritime cultural heritage.

Urban revitalization projects, including places where cultural heritage sites or places of cultural importance are located, may also benefit from financed engineering mechanisms such as equity loans or guarantees during the programming period 2014-2020.

In addition, the European Commission supports the development of responsible and sustainable tourism, including products related to cultural and industrial heritage, as well as activities related to giving a new role and importance to traditional skills and crafts. Supports actions to increase the importance and attractiveness of cultural professions and to provide greater opportunities for lifelong learning. In this case, there is a possibility to use the resources offered by the European Social Fund.

Because of the limitations of this publication, this is only a brief overview of the European Union policy concerning cultural heritage and the possibility of obtaining funding for various projects associated with it.

\section{Conclusions}

Cultural heritage is undoubtedly an important factor in the development of cities, villages, and regions. It is a key element of international dialogue not only on the European Union but on a global scale. Humanity already in the second half of the twentieth century launched an integrated policy of heritage protection. And despite the fact this policy was significantly limited and focused mainly on protecting of material heritage from degradation and destruction, it launched an important for humanity process which continues today and will continue in the future. Europe's citizens not only appreciate the value of cultural heritage but also seek the best opportunities to use it for economic, social, cultural and environmental purposes. They no longer perceive this good only in the context of the rising costs of maintaining and legal protection. They see in it the sources of income, opportunities for social inclusion, job creation, preserving of lost jobs and crafts, the strengthening of social ties, the protection of the environment and many other benefits.

The EU authorities not only stress the importance of the heritage and support its protection and economic use, but also provide the opportunity to finance a broadly understood heritage from a variety of sources and programs.

Therefore, it is worth considering whether the old little church at the crossroads or old already closed and abandoned factory will not give a new meaning to the village, the city or the region. But this is a task for local governments as well as for the local communities, SMEs, artists and other people and organizations that can contribute to the creative re-use of cultural heritage.

\section{References}

CHCfE Consortium (2015). Cultural heritage counts for Europe. Full report. Retrieved from: http://blogs.encatc.org/culturalheri tagecountsforeurope//wp-content/uploads/2015/06/CHCfE_FULL-REPORT_v2.pdf.

European Commission (2007). European agenda for culture in a globalizing world. Retrieved from: http://eur-lex.europa.eu/legal-content/ PL/ALL/?uri=CELEX\%3A52007DC0242. 
European Commission (2010). Europe 2020. A strategy for smart, sustainable and inclusive growth (COM(2010) 2020 final). Retrieved from: http:/leur-lex.europa.eu/legal content/EN/TXT/PDF/?uri=CELEX:52010DC2020\&from=en.

European Commission (2014). Towards an integrated approach to cultural heritage for Europe. Retrieved from: http://eur-lex.europa.eu/ legal-content/en/TXT/?uri=CELEX\%3A52014DC0477.

Międzynarodowe Centrum Kultury (2015). Dziedzictwo kulturowe ma znaczenie dla Europy. Skrót raportu. Retrieved from: http://blogs. encatc.org/culturalheritagecountsforeurope/wp-content/uploads/2015/09/CHCFE_Raport_PL.pdf.

Jurkiewicz-Eckert, D. (2003). Od „wspólnego dziedzictwa kulturowego” do „wspólnego obszaru kulturowego”. O nowych kierunkach debaty wokół przyszłości kultury w Unii Europejskiej. Studia Europejskie, 3, 81-95.

Mkadem, A.B., Zakriti, A., Nieuwenhuysen, P. (2018). Pay or preserve: a new approach to valuing cultural heritage. Journal of Cultural Heritage Management and Sustainable Development, 8 (1), 2-16.

Murzyn-Kupisz, M. (2010). Barbarzyńca w ogrodzie? Dziedzictwo kulturowe widziane z perspektywy ekonomii. Zarządzanie Publiczne, 3 (13), 19-31.

Official Journal of the European Union (2007). European Agenda for Culture. Retrieved from: http://eur-lex.europa.eu/legal content/EN/ TXT/?uri=CELEX\%3A32007G1129\%2801\%29.

Official Journal of the European Union (2012). Consolidated versions of the Treaty on European Union and the Treaty on the Functioning of the European Union. Retrieved from: https://eur-lex.europa.eu/legal-content/EN/TXT/PDF/?uri=OJ:C:2016:202:FULL\&from= EN.

UNESCO (1972). Convention concerning the protection of the World Cultural and Natural heritage. Retrieved from: http://whc.unesco. org/archive/convention-en.pdf.

Wikipedia (2017). Definition of cultural heritage Retrieved from: https://en.wikipedia.org/wiki/Cultural_heritage.

Cite this article aS: Niemczewska, Z.E. (2018). The European Union funds in the implementation of the concept of sustainable development in the context of financing projects related to the re- use of Europe's cultural heritage. European Journal of Service Management, 3 (27/2), 307-313. DOI: 10.18276/ejsm.2018.27/2-37. 